\title{
Short Communication: Local perceptions about utilization of invasive alien species Opuntia ficus-indica in three Local Municipalities in the Eastern Cape Province, South Africa
}

\author{
LULEKA MDWESHU, ALFRED MAROYI ${ }^{\vee}$ \\ Medicinal Plants and Economic Development Research Centre, Department of Botany, University of Fort Hare. Private Bag X1314, Alice 5700, South \\ Africa. Tel.: +27-719600326; `email: amaroyi@ufh.ac.za
}

Manuscript received: 8 February 2020. Revision accepted: 26 March 2020.

\begin{abstract}
Mdweshu L, Maroyi A. 2020. Short Communication: Local perceptions about utilization of invasive alien species Opuntia ficus-indica in three Local Municipalities in the Eastern Cape Province, South Africa. Biodiversitas 21: 1653-1659. Opuntia ficusindica is a succulent plant species categorized as invasive in South Africa but has both commercial and non-market uses. This study evaluated local people's perceptions about utilization of $O$. ficus-indica in three local Municipalities in the Eastern Cape province of South Africa. Data on the local perceptions on $O$. ficus-indica in the study area were documented through focus group discussions and semi-structured interviews via questionnaires with households between June 2018 and August 2019. A sample of 150 participants chosen using snowball-sampling method provided information on utilization of $O$. ficus-indica. The importance of $O$. ficus-indica as a useful plant species was ubiquitously perceived, with all participants reporting its contribution as an important component of their livelihood needs and more than three quarters $(88.0 \%)$ were using the species on a regular basis. Close to half of the respondents (49.3\%) regarded $O$. ficus-indica as an important source of cash income. The positive socio-economic contributions of $O$. ficus-indica need to be taken into account when evaluating the costs and benefits resulting from invasions caused by alien plant species.
\end{abstract}

Keywords: Local community, Opuntia ficus-indica, perceptions, South Africa, succulent plant, traditional knowledge

\section{INTRODUCTION}

Opuntia ficus-indica (L.) Mill. is a succulent species that belongs to the Cactaceae or cactus family. Opuntia ficus-indica originated in Mexico and the neighboring middle-America but the species is now categorized as an invasive alien plant species in South Africa where the species has been part of the country's landscapes for over 250 years (Shackleton et al. 2011; Shackleton 2012). Therefore, O. ficus-indica is an appropriate species to be used as a model to assess local people's perceptions about the detrimental or beneficial characteristics of an invasive alien species. As invasive species move and occupy new areas or regions, usually their movement results in negative effects on economic, social and/or ecological systems (Van Wilgen and Wannenburgh 2016). The invasive alien species are known to be the major causes of global environmental change and are indicated as the second largest cause of species threat and extinction where there is destruction of the natural habitat (Pejchar and Money 2009). The invasive alien species also pose a serious threat to natural ecosystems that provide basic human securities such as health, food, shelter, good social relations and freedom (Scoones 2009). Research by Shackleton and Shackleton (2018) emphasized the importance of assessing the positive and negative impacts of alien plant species. Some researchers also argue that several invasive species are important to local communities mainly because local people derive direct benefits from invasive alien species (Shackleton et al. 2019). Research by Rai et al. (2012) and Atyosi et al. (2019) showed that some alien plant species serve as pioneer communities and are also used as organic compost by some farming communities. Rai et al. (2012) argued that alien plant species such as Chromolaena odorata (L.) R.M. King \& H. Rob. are widely used as compost and green manure in Nepal and are known to improve both the physical and chemical properties of the soil.

The increase in trade, transportation of goods and humans led to the increased movement of many alien species (Lindemann-Matthies 2016). As humans take an active part in the introduction, establishment, and spread of invasive species, it is necessary to understand human perceptions and choices regarding the use and management of invasive species (Bardsley and Edwards-Jones 2007; Keller et al. 2011; Bennett 2016; Nanayakkara et al. 2018; Potgieter et al. 2019; Shrestha et al. 2019; Wald et al. 2019). The term perception is defined as the process by which each individual person organizes, selects and assesses the sensory stimulations from the external living and non-living environment to provide meaningful experiences to different individuals (Atmadja and Sills 2016). Other researchers like Schermerhorn et al. (2002) and Shackleton et al. (2019) defined perceptions as processes where individuals organize, select, retrieve, 
respond and interpret obtained information from the environment around them to produce mental impressions and constructions which lead to particular behaviors and actions. Therefore, perceptions are usually influenced by social-ecological factors, including socio-economic characteristics of local people, the biology and ecology of invasive species, economic factors and social influences (Shackleton et al. 2019). It is within this background that this study was carried out aimed at investigating the local people's perceptions about utilization of $O$. ficus-indica in three local Municipalities in the Eastern Cape province of South Africa. We will address the following research questions: which are the most important uses of $O$. ficusindica locally? How does utilization of $O$. ficus-indica contribute to the livelihood needs of local people?

This study is premised on developing an understanding of local knowledge and perceptions about $O$. ficus-indica. Such human and social dimension is important for effective management of invasive alien species as many control, eradication or prevention programs have been delayed or even failed due to differing public attitudes and feelings towards targeted invasive species (Meyer and Fourdrigniez 2019). Proponents of people-centered approaches to invasive alien species management (Santo et al. 2015; Lurgi et al. 2016; Bravo-Vergas et al. 2019; Martínez and Manzano-García 2019) argue that this management strategy is premised on ensuring social equity in conservation as it minimizes conflict between local communities and conservation organizations. Therefore, the negative and positive impacts of invasive alien species could be reliably assessed through an evaluation of local knowledge and the social benefits associated with such species.

\section{MATERIALS AND METHODS}

\section{Study areas}

The research focuses on three local municipalities within the Eastern Cape province in South Africa, the Makana, Ngqushwa and Raymond Mhlaba Local Municipalities (Figure 1). The population density of Ngqushwa (32 people per $\mathrm{km}^{2}$ ) is significantly higher than that of Raymond Mhlaba (24 people per $\mathrm{km}^{2}$ ) and Makana (18 people per $\mathrm{km}^{2}$ ) (Statistics South Africa 2016). The climate of the study area is mild with unevenly distributed annual rainfall received during summer months from October to March. Annual rainfall ranges from $500 \mathrm{~mm}$ to $1000 \mathrm{~mm}$ while temperature ranges from $4^{\circ} \mathrm{C}$ in July to $38^{\circ} \mathrm{C}$ in February (Jari and Fraser 2012; Manyevere et al. 2014). In spite of unfavorable agro-ecological conditions, households practice both livestock husbandry (Ndhleve et al. 2013) and are involved in the production of maize, sorghum, potatoes, cabbage, spinach, beetroot and carrots. The residents also rely on natural plant resources for a diversity of livelihood needs (Alexander et al. 2015). The vegetation of the study area was described by Mucina and Rutherford (2006) as succulent thicket and grassland biomes.

\section{Data collection}

This study utilized the participatory rural appraisal (PRA) methods (Chambers 1994), focusing on in-depth discussions using open-ended questionnaires and participant observation with local communities in data gathering. The current study documented local people's perceptions about utilization of $O$. ficus-indica in Makana, Ngqushwa and Raymond Mhlaba Local Municipalities, a species that

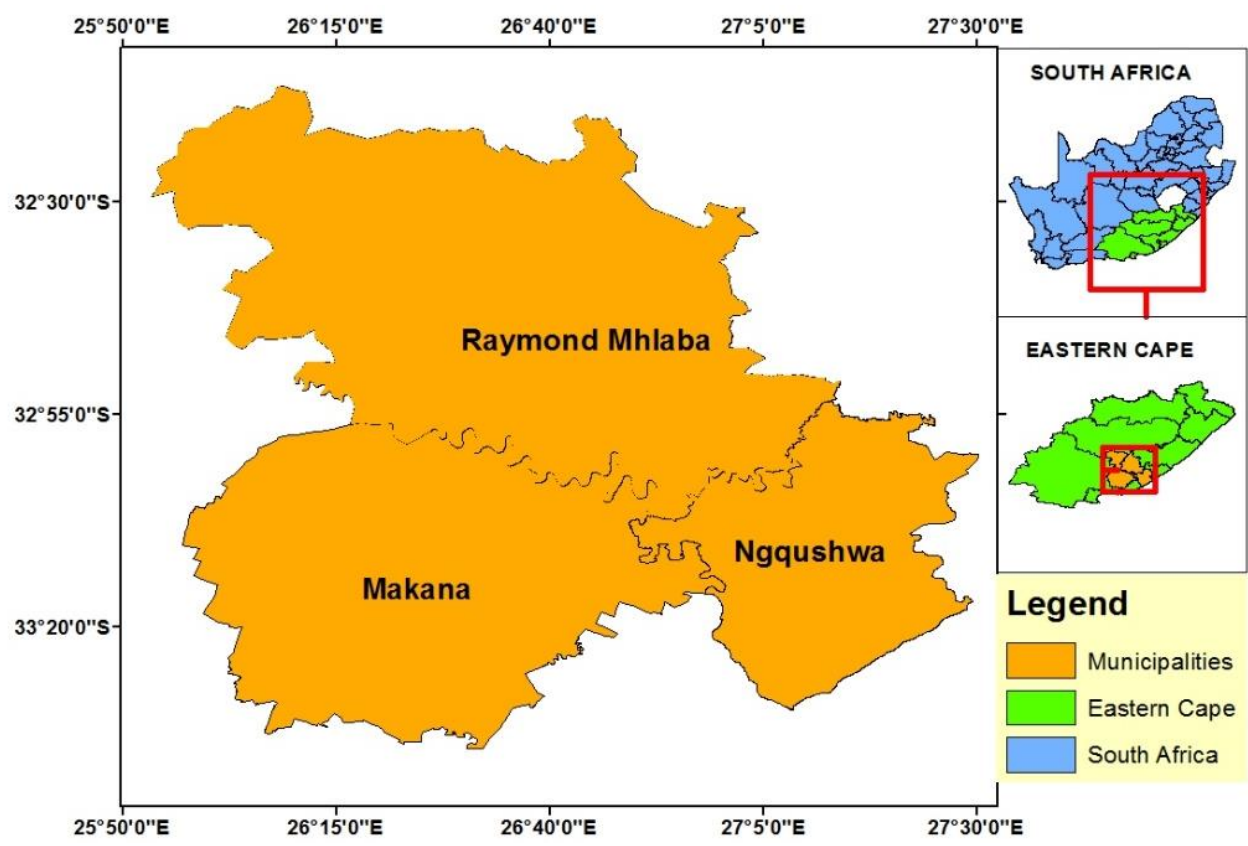


Figure 1. The geographical position of study areas across three local Municipalities in the Eastern Cape Province, South Africa

has been in usage in the region since the 1770s (Annecke and Moran 1978). One hundred and fifty participants selected from Makana, Ngqushwa and Raymond Mhlaba Local Municipalities through snowball or chain sampling (Heckathorn 2011) were interviewed between June 2018 and August 2019. The questionnaire emphasized socioeconomic characteristics of the participants and the following aspects meant to assess participants' perceptions on the biology, use values and management of $O$. ficusindica as a declared invader plant species according to the South African National Environmental Management: Biodiversity Act 2004 (Government Gazette 2004): (i) Are there any $O$. ficus-indica plants in this village? If yes, is the species common in the village? (ii) Do you know any uses of $O$. ficus-indica? (iii) Who uses these products? How do users obtain these products? (iv) Do you know that $O$. ficus-indica is a weed? If yes, how do you know about this? (v) Do you think that $O$. ficus-indica should be eradicated? If yes, how do you think this can be done? (vi) What is your opinion about categorization of $O$. ficus-indica as a weed in South Africa?

In terms of the questions on the perceptions on the biology, use values and management of $O$. ficus-indica, these were open-ended so as to avoid leading the participants. The responses from the PRA interviews and focus group discussions (FGD) were written down in a notebook as well as tape-recorded.

\section{Data analysis}

Some of the data in this study were explained directly because these data were descriptive and qualitative in nature. However, some interview data were coded, divided into themes using content analysis (Msuya and Wambura 2016; Erlingsson and Brysiewicz 2017). Responses from the questionnaire and FGDs were analyzed by identifying similar phrases, patterns, sequences, relationships and differences as outlined by Erlingsson and Brysiewicz (2017).

\section{RESULTS AND DISCUSSION}

\section{Socio-economic characteristics of the respondents}

The majority of the participants $(54.0 \%)$ who provided information on their perceptions about the biology, livelihood uses, and management of $O$. ficus-indica in the study areas were females while $46.0 \%$ were males. About two-thirds of the respondents $(67.3 \%)$ were between 31 years to 60 years, while $14.0 \%$ were below 31 years and $18.7 \%$ were above 60 years of age. About a third of the participants, $32.0 \%$ and $34.7 \%$, were married and single, respectively, while $24.7 \%$ were widowed and $8.7 \%$ were divorced. The majority of families ( $68.0 \%$ of households) comprised between one and five household members, while $26.0 \%$ comprised of six to ten household members and $6.0 \%$ had more than ten household members. Most of the respondents were educated up to primary and secondary level $(42.7 \%$ and $44.0 \%$, respectively) and less than ten percent were either illiterate or educated up to tertiary level (5.3\% and $8.0 \%$, respectively). The majority of the participants $(56.0 \%)$ were unemployed, $26.7 \%$ were selfemployed, $13.3 \%$ employed by a private company and $4.0 \%$ employed by government. Close to a third of the participants were dependent on their pension (28.0\%), while $23.3 \%$ of the participants were managing small informal businesses, $17.3 \%$ depended on remittances and $14.7 \%$ depended on government grants. The majority of participants $(40.7 \%)$ had total annual income of R2 000.00 to R10 000.00 (US\$142.86 to US\$714.29) per month, $30.7 \%$ (>R10 000.00 (US\$714.29), $18.7 \%$ (R200.00 to R1999.99 (US\$14.29 to US\$142.86) and less than ten percent had either monthly income not exceeding R199.99 (US\$14.29) or did not disclose their income.

\section{Perceptions and utilization of Opuntia ficus-indica}

The importance of $O$. ficus-indica as a useful plant species was ubiquitously perceived, with all participants reporting its contribution towards their livelihood needs and more than three quarters $(88.0 \%)$ using the species on a regular basis. Although $12.0 \%$ were not personally using O. ficus-indica, all respondents claimed that the species is one of the most useful natural resources in the province. Table 1 shows the respondents' perceptions of benefits associated with $O$. ficus-indica. During FGDs and it was revealed that more than three-quarters of the respondents $(79.3 \%)$ did not know O. ficus-indica is alien to South Africa, with most respondents expressing surprise when the researcher mentioned that it is originally from Mexico and the neighboring middle-America. Figure 2 shows the number of years the respondents have been using O. ficusindica. The majority of respondents (32.0\%) had been using the species for more than 13 years, followed by the respondents who have been using the species for 10 years to 12 years, and seven years to nine years with $23.0 \%$ and $21.0 \%$, respectively. The minority $(6.0 \%)$ of the respondents have been using the species for less than a year to three years (Figure 2). All the respondents argued that $O$. ficus-indica has been in use in the province for generations with a village in Raymond Mhlaba Local Municipality called "Tolofiyeni", named after the vernacular name of $O$. ficus-indica.

Respondents provided a number of reasons to justify their attitudes and reasons regarding utilization of $O$. ficusindica (Table 2). Majority of the participants $(88.6 \%$ and $84.1 \%$ ) argued that $O$. ficus-indica is required as an important source of livelihood needs and/or supplementing or complementing household food, fodder, income, hedge, fence, herbal medicines, homemade soap and beer brewing (Table 2). About $8.3 \%$ of the respondents emphasized the aesthetic role played by $O$. ficus-indica as hedge or live fence and the species is now regarded as an important component of the Eastern Cape province landscape. About $6.1 \%$ of the respondents argued that $O$. ficus-indica is now regarded as an integral part of the social and cultural framework for the local communities in the Eastern Cape with participants emphasizing the use of the species as herbal medicine, beer brewing and the fruits donated to 
neighbors or used as gifts to relatives or neighbors (Table 2 ). Focus group discussions with the respondents revealed that usage of $O$. ficus-indica fruits was a form of cultural identity that is always attached to the species by the rural people as they had grown up eating the fruits. Some of the respondents argued that eating of the fruits is part of their tradition with all respondents perceived $O$. ficus-indica to have been there before they were born. Interviews with respondents revealed that processes of gathering and processing $O$. ficus-indica result in important social benefits as local people cooperate in these activities. The social interactions associated with gathering and processing $O$. ficus-indica could be the basis for community-based systems for managing plant resources. A small proportion of the respondents $(1.5 \%)$ argued that there was need to highlight the fact that $O$. ficus-indica is an invasive alien species in need of monitoring and control, and there is need to participate in integrated clearing program of the species that is coordinated by Working for Water organization (Table 2).

These respondents argued that the Working for Water Programme significantly increased public awareness about alien species in the Eastern Cape, including O. ficus-indica. During FGDs, the respondents argued that $O$. ficus-indica was inextricably linked to local peoples' food needs, nutrition, health, culture and landscape in a number of fundamental ways. Discussions with respondents during FGDs also revealed that $O$. ficus-indica helps to diversify the household economy, providing seasonal source of income between December and March every year. This small-scale processing and trade of $O$. ficus-indica make up an important part of the rural economy in the province. Interviews with the respondents revealed that the income generated through selling $O$. ficus-indica fruits is used for livelihood needs such as buying electricity, groceries, clothing, school fees, and uniform.

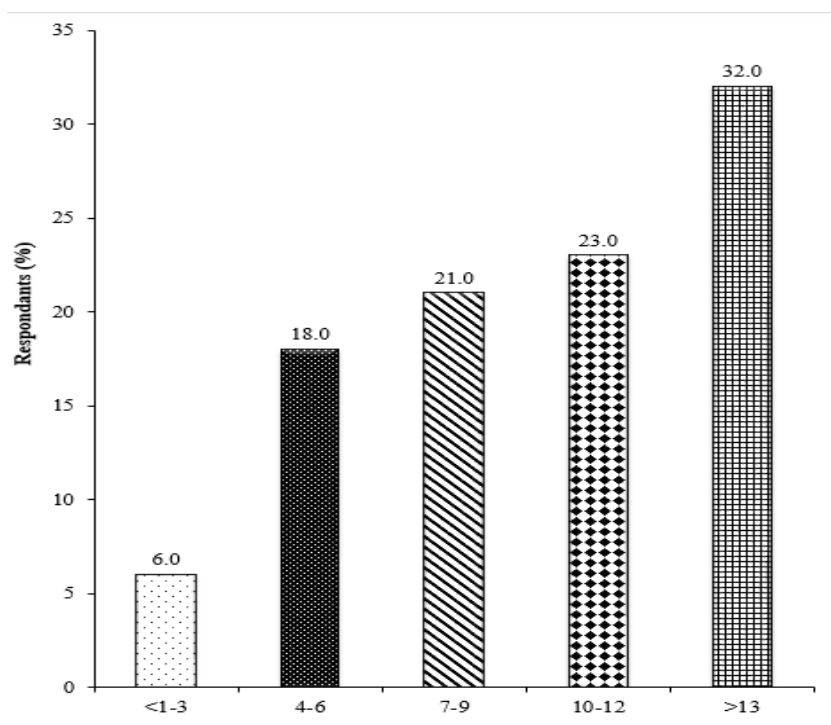

Figure 2. Number of years of using Opuntia ficus-indica by respondents in the Eastern Cape, South Africa $(n=132)$
Table 1. Respondents' perceptions of the benefits associated with Opuntia ficus-indica $(\mathrm{n}=150)$. Some respondents indicated more than one response.

\begin{tabular}{|c|c|}
\hline Reasons & $\begin{array}{l}\text { Response } \\
(\%)\end{array}$ \\
\hline \multicolumn{2}{|l|}{$\begin{array}{l}\text { Respondents deriving benefits from } O \text {. ficus- } \\
\text { indica }\end{array}$} \\
\hline $\begin{array}{l}\text { Households generate income from selling the } \\
\text { fruits }\end{array}$ & 49.3 \\
\hline $\begin{array}{l}\text { Households making jam, syrup, chutney, and } \\
\text { beer from the fruits }\end{array}$ & 20.7 \\
\hline O. ficus-indica used as herbal medicine & 12.3 \\
\hline $\begin{array}{l}\text { O. ficus-indica used as live fence, hedge or } \\
\text { ornamental plant }\end{array}$ & 5.3 \\
\hline O. ficus-indica used as fodder & 4.7 \\
\hline \multicolumn{2}{|l|}{ Respondents not benefiting from $O$. ficus-indica } \\
\hline O. ficus-indica not useful to the community & 2.7 \\
\hline $\begin{array}{l}\text { There are challenges associated with harvesting } \\
\text { and transporting } O \text {. ficus-indica }\end{array}$ & 8.6 \\
\hline $\begin{array}{l}\text { O. ficus-indica is no-long available in some } \\
\text { communities }\end{array}$ & 3.3 \\
\hline $\begin{array}{l}\text { Selling } O \text {. ficus-indica fruits is not profitable as } \\
\text { the prices are too low }\end{array}$ & 1.3 \\
\hline
\end{tabular}

Table 2. People's attitudes or reasons for using $O$. ficus-indica in Makana, Ngqushwa and Raymond Mhlaba Local Municipalities in the Eastern Cape, South Africa $(n=132)$. Some respondents indicated more than one response.

\section{Major reason and specific components (\%) \\ Supplementary role (as fodder, food, hedge, fence,} beer brewing, herbal medicine, homemade soap and source of income)

Livelihood needs (as fodder, food, hedge, fence, herbal medicine and source of income)

Aesthetic role (hedge, live fence, ornamental and garden plant, and an important component of the Eastern Cape province landscape)

Cultural role (as herbal medicine, beer brewing, fruits donated to neighbors and used as gifts to relatives and neighbors)

An invasive alien species in need of monitoring and control

\section{Discussion}

Socio-economic characteristics of the respondents

The average annual household income within the sampled community population was low as well as literacy levels with $48.0 \%$ either illiterate or educated up to primary level (Table 1) and this is probably due to limited education facilities within the study area. Makiwane and ChimereDan (2010) argued that quality of education in the Eastern Cape province is among the poorest in the country. The same authors argued that there have been some improvements in the educational profile of the provisional population but access to high-quality infrastructure for learning and other better models of human capital development in the province remain a challenge. Similarly, Hamann and Tuinder (2012) and Megbowon and Mushunje 
(2018) argued that the levels of education, skills base, infrastructure, healthcare services and poverty in the province are the worst in the country in comparison to other provinces in the country. The authors argued that these socio-economic problems in the province cannot be separated from the lasting legacy of the Apartheid government. Hamann and Tuinder (2012) noted that one of the Apartheid government's acts of segregation was the Bantu Authorities Act of 1951 which legalized the deportation of blacks into designated homelands or "Bantustans" like Ciskei where two of the study sites Ngqushwa and Raymond Mhlaba Local Municipalities are located. Research by Paumgarten et al. (2005) revealed that the majority of the areas in the former homelands such as Ciskei and Transkei in the province are characterized by a strong reliance on migrant remittances and state pensions, low economic activity, low levels of education and poor skills base.

\section{Perceptions and utilization of $O$. ficus-indica}

A significant number of respondents (88.0\%) emphasized the importance of $O$. ficus-indica to the livelihood needs of the local people in Makana, Ngqushwa and Raymond Mhlaba Local Municipalities. Local communities have incorporated $O$. ficus-indica into their livelihoods which resulted in respondents not knowing that the species is an alien. To the local communities in Makana, Ngqushwa and Raymond Mhlaba Local Municipalities, O. ficus-indica is categorized or recognized like any other indigenous useful plant species in the province. Such a perception was observed by dos Santos et al. (2014) who argued that there is often no differentiation by local communities between invasive alien species and native species as local communities often focus on the ecosystem goods and services provided by such species. Research findings from the current investigation corroborate previous studies which showed that invasive alien plant species may also have positive socio-economic benefits (Zimmermann and Neser 1999; Njoroge et al. 2004; Bigirimana et al. 2011, 2012; Semenya et al. 2012a,b; Maroyi 2017a,b, 2018; Semenya and Maroyi 2018). Borokini and Babalola (2012) argued that economic exploitation of invasive alien species is usually labor intensive and menial jobs are usually created while providing additional means of income for local communities. Similarly, Sladonja et al. (2018) argued that invasive alien plants can be used as catalysts for ecosystem restoration, source of bioenergy, honey, fiber, ornamental plants, and herbal medicines. Exotic plant species are now regarded as an important component of traditional pharmacopeia in many developing countries (Bennett and Prance 2000; Alencar et al. 2010, 2014; Borokini and Babalola 2012; Maroyi 2018; Semenya and Maroyi 2018; Sladonja et al. 2018).

For the poor households, collection of $O$. ficus-indica is a means of coping with food-supply, nutrition and cash income needs (Palmer 2004). Households living near suitable habitats for $O$. ficus-indica are typically most dependent on the species and these people are the most active collectors of $O$. ficus-indica in the study area. In several villages within Makana, Ngqushwa and Raymond Mhlaba Local Municipalities, the collection and gathering of $O$. ficus-indica were used as a means to manage poverty and to empower local community development in different ways including community engagement, incomegenerating activities and cultural diversity. There is no doubt that the production of $O$. ficus-indica will enable poor households to continue to exploit the full potential of the species.

In conclusion, this study showed that although O. ficusindica is listed as a weed, category $1 \mathrm{~b}$ invader in the National Environmental Management Biodiversity Act No. 10 of 2004 (Annecke and Moran 1978; Government Gazette 2004) in South Africa, the species has positive economical, social and ecological impacts in the study area. These socio-economic contributions of the species need to be taken into account when assessing the costs resulting from invasions caused by alien plant species. This research provides baseline information regarding utilization of $O$. ficus-indica in the Eastern Cape province and the utilization pattern of the species and can be easily applied to other useful invasive plant species. Based on the results of this study, the policymakers, government officers, agricultural extension officers, non-governmental organizations (NGO), conservation managers and future researchers on the species need to address these concerns and attempt to find a balance between removing the species because of its invasive characteristics and the associated negative ecological impacts on ecosystem services and biodiversity; and the need to keep the species, particularly where $O$. ficus-indica invasions are not significant, but the species is used to fulfill the livelihood needs of the local communities.

\section{ACKNOWLEDGEMENTS}

The authors would like to express their gratitude to Govan Mbeki Research and Development Centre (GMRDC), University of Fort Hare, South Africa for financial support.

\section{REFERENCES}

Alencar NL, de Sousa TAA, de Amorim ELC, de Albuquerque UP. 2010. The inclusion and selection of medicinal plants in traditional pharmacopoeias-evidence in support of the diversification hypothesis. Econ Bot 64: 68-79.

Alencar NL, Santoro FR, de Albuquerque UP. 2014. What is the role of exotic medicinal plants in local medical systems? A study from the perspective of utilitarian redundancy. Revista Brasil Farmacogn 24: 506-515.

Alexander J, Cocks ML, Shackleton C. 2015. The landscape of childhood: play and place as tools to understanding children's environmental use and perceptions. Hum Ecol 43: 467-480.

Annecke DP, Moran VC. 1978. Critical reviews of biological pest control in South Africa: The prickly pear, Opuntia ficus-indica (L.). J Entomol Soc South Afr 41: 161-188.

Atmadja SS, Sills EO. 2016. What is a "community perception" of REDD+? A systematic review of how perceptions of REDD+ have been elicited and reported in the literature. PLoS ONE 11: e0155636. DOI: 10.1371/journal.pone.0155636 
Atyosi Z, Ramarumo LJ, Maroyi A. 2019. Alien plants in the Eastern Cape province in South Africa: Perceptions of their contributions to livelihoods of local communities. Sustainable 11: 5043

Bardsley DK, Edwards-Jones G. 2007. Invasive species policy and climate change: Social perceptions of environmental change in the Mediterranean. Environ Sci Pol 10: 230-242.Bennett NJ. 2016. Using perceptions as evidence to improve conservation and environmental management. Cons Biol 30: 582-592.Bennett BC, Prance GT. 2000. Introduced plants in the indigenous pharmacopoeia of Northern South America. Econ Bot 54: 90-102.

Bigirimana J, Bogaert J, De Canniere C, Bigendako M-J, Parmentier I 2012. Domestic garden plant diversity in Bujumbura, Burundi: Role of the socio-economical status of the neighbourhood and alien species invasion risk. Landscape Urban Plan 107: 118-126.

Bigirimana J, Bogaert J, De Canniere C, Lejoly J, Parmentier I. 2011. Alien plant species dominate the vegetation in a city of sub-Saharan Africa. Landscape Urban Plan 100: 251-267.

Borokini TI, Babalola FD. 2012. Management of invasive plant species in Nigeria through economic exploitation: lessons from other countries. Manag Biol Invas 3: 45-55.

Bravo-Vargas V, García RA, Pizarro C, Pauchard A. 2019. Do people care about pine invasions? Visitor perceptions and willingness to pay for pine control in a protected area. J Environ Manag 229: 57-66.

Brown KA, Flynn DF, Abram NK, Ingram JC, Johnson SE, Wright P. 2011. Assessing natural resource use by forest-reliant communities in Madagascar using functional diversity and functional redundancy metrics. PLoS ONE 6(9): e24107.

Chambers R. 1994. The origins and practice of Participatory Rural Appraisal. World Develop 22: 953-969.

dos Santos LL, do Nascimento ALB, Vieira FJ, da Silva VA, Voeks R, de Albuquerque UP. 2014. The cultural value of invasive species: A case study from semi-arid northeastern Brazil. Econ Bot 68: 283-300.

Government Gazette, 2004. National Environmental Management Biodiversity Act No.10 of 2004. Department of Environmental Affairs and Tourism (DEAT), Pretoria, South Africa.

Erlingsson C, Brysiewicz P. 2017. A hands-on guide to doing content analysis. Afr J Emergency Med 7(3): 93-99.

Hamann M, Tuinder V. 2012. Introducing the Eastern Cape: A quick guide to its history, diversity and future challenges. Stockholm University, Stockholm Resilience Centre, Stockholm University, Stockholm, Sweden.

Heckathorn DD. 2011. Snowball versus respondent-driven sampling Sociol Method 41: 355-366.

Jari B, Fraser GCG. 2012. Influence of institutional and technical factors on market choices of smallholder farmers in the Kat River Valley. In Van Schalkwyk HD, Groenewald JA, Fraser GCG, Obi A, Van Tilburg A (Eds.), Unlocking markets to smallholders: Lessons from South Africa. Wageningen Academic Press, Wageningen, The Netherlands.

Keller RP, Geist J, Jeschke JM, Kühn I. 2011. Invasive species in Europe: Ecology, status, and policy. Environ Sci Europe 23: 1-17.LindemannMatthies P. 2016. Beasts or beauties? Laypersons' perception of invasive alien plant species in Switzerland and attitudes towards their management. NeoBiota 29: 15-33.

Lurgi M, Wells K, Kennedy M, Campbell S, Fordham DA. 2016. A landscape approach to invasive species management. PLoS One 11(7): e0160417.

Makiwane MB, Chimere-Dan DOB. 2010. The people matter: The state of the population in the Eastern Cape. Research and Population Unit Eastern Cape Department of Social Development, East London, South Africa.

Manyevere A, Muchaonyerwa P, Laker MC, Mnkeni PNS. 2014. Farmers' perspectives with regard to crop production: An analysis of Nkonkobe Municipality, South Africa. J Agr Rural Develop Trop Subtrop 115: 41-53.

Maroyi A. 2017a. Assessment of useful plants in the catchment area of the proposed Ntabelanga Dam in the Eastern Cape province, South Africa. Scient World J: art. 3763607.

Maroyi A. 2017b. Diversity of use and local knowledge of wild and cultivated plants in the Eastern Cape province, South Africa. J Ethnobiol Ethnomed 13: 10.

Maroyi A. 2018. Ethnomedicinal uses of exotic plant species in southcentral Zimbabwe. Indian J Trad Knowl 17: 71-77.

Martínez GJ, Manzano-García J. 2019. Perception and use of non-native and invasive flora from Sierras de Córdoba in central Argentina. Acta Bot Brasilica 33(2): 241-253.
Megbowon ET, Mushunje A. 2018. Assessment of food security among households in Eastern Cape province, South Africa: Evidence from general household survey, 2014. Intl J Soc Econ 45: 2-17.

Meyer J-Y, Fourdrigniez M. 2019. Islander perceptions of invasive alien species: the role of socio-economy and culture in small isolated islands of French Polynesia (South Pacific). In: Veitch CR, Clout MN, Martin AR, Russell JC, West CJ (Eds.), Island invasives: scaling up to meet the challenge. Occasional Paper SSC no. 62, IUCN, Gland, Switzerland.

Mucina L, Rutherford MC. 2006. The vegetation of South Africa, Lesotho and Swaziland. South African National Biodiversity Institute, Pretoria, South Africa.

Msuya CP, Wambura RM. 2016. Factors influencing extension service delivery in maize production by using agricultural innovation system in Morogoro and Dodoma regions, Tanzania. S Afr J Agr Ext 44: 248-255.

Nanayakkara L, Juri-Hage R, Leavitt P, Wissel LB. 2018. In lakes but not in minds: Stakeholder knowledge of invasive species in prairie lakes. Biol Inv 20: 633-654.

Ndhleve S, Musemwa L, Zhou L. 2013. How severe hunger is amongst rural households of the Eastern Cape province of South Africa. J Econ Sustain Develop 4: 220-227.

Njoroge NG, Bussmann WR, Gemmill B, Newton LE, Ngumi VW. 2004 Utilisation of weed species as sources of traditional medicines in central Kenya. Lyonia 7: 71-87.

Palmer CT. 2004. The inclusion of recently introduced plants in the Hawaiian ethnopharmacopoeia. Econ Bot 58: S280-S293.

Paumgarten F, Shackleton CM, Cocks ML. 2005. Growing trees in homegardens by rural households in the Eastern Cape and Limpopo provinces, South Africa. Int J Sustain Develop World Ecol 12: 1-19.

Pejchar L, Money H. 2009. Invasive species, ecosystem services and human well-being. Trends Ecol Evol 24: 497-504.

Potgieter L, Gaertner M, O'Farrell PJ, Richardson DM. 2019. Perceptions of impact: invasive alien plants in the urban environment. J Environ Manag 229: 76-87.

Rai R.J., Scarborough H, Subedi N, Lamichhmane B. 2012. Invasive plants: Do they devastate or diversify rural livelihoods? Rural farmer's perception of three invasive plants in Nepal. J Nature Cons 20: $170-176$.

Santo AR, Sorice MG, Donlan CJ, Franck CT, Anderson CB. 2015. A human-centered approach to designing invasive species eradication programs on human-inhabited islands. Global Environ Change 35: 289-298.

Schermerhorn JR, Hunt J, Osborn RN, 2002. Organizational behaviour. Wiley and Sons, New York, USA

Scoones I. 2009. Livelihoods perspectives and rural development. J Peasant Stud 36: 171-196

Semenya SS, Potgieter MJ, Tshisikhawe MP. 2012a. Invasive alien plant species: A case study of their use in the Thulamela Local Municipality, Limpopo province, South Africa. Scient Res Essays 7: 2363-2369.

Semenya SS, Potgieter MJ, Tshisikhawe MP, Shava S, Maroyi A. 2012 b. Medicinal utilization of exotic plants by Bapedi traditional healers to treat human ailments in Limpopo Province, South Africa. J Ethnopharmacol 144: 646-655.

Semenya SS, Maroyi A. 2018. Exotics plants used therapeutically by Bapedi traditional healers for respiratory infections and related symptoms in the Limpopo province, South Africa. Indian J Trad Knowl 17: 663-671.

Sladonja B, Poljuha D, Uzelac M. 2018. Non-native invasive species as ecosystem service providers. In: Hufnagel L (Ed.), Ecosystem services and global ecology. Intechopen, London, UK.

Shackleton S. 2012. Prickly pear: The social history of a plant in the Eastern Cape. Afr J Range For Sci 29: 157-158.

Shackleton SE, Shackleton RT. 2018. Local knowledge regarding ecosystem services and disservices from invasive alien plants in the arid Kalahari, South Africa. J Arid Environ 159: 22-33.

Shackleton S, Kirby D, Gambiza J. 2011. Invasive plants: Friends or foes? Contribution of prickly pear (Opuntia ficus-indica) to livelihoods in Makana Municipality, Eastern Cape, South Africa. Develop Southern Afr 28: 177-193

Shackleton RT, Richardson DM, Shackleton CM, Bennett B, Crowley SL, Dehnen-Schmutz K, Estévez RA, Fischer A, Kueffer C, Kull CA, Marchante E, Novoa A, Potgieter LJ, Vaas J, Vaz AS, Larson BMH. 2019. Explaining people's perceptions of invasive alien species: A conceptual framework. J Environ Manag 229: 10-26. 
Shrestha BB, Shrestha UB, Sharma KP, Thapa-Parajuli RB, Devkota A, Siwakoti M. 2019. Community perception and prioritization of invasive alien plants in Chitwan-Annapurna Landscape. Nepal J Environ Manag 229: 38-47.

Statistics South Africa, 2016. Community survey: agricultural households. Available

from: http://www.statssa.gov.za/publications/03005/Presentation

CS2016_Agricultural_Households.pdf, accessed on 20 August 2019.
Van Wilgen BW, Wannenburgh A. 2016. Co-facilitating invasive species control, water conservation and poverty relief: Achievements and challenges in South Africa's Working for Water programme. Curr Opin Environ Sustain 19: 7-17.

Wald DM, Nelson KA, Gawel AM, Rogers HS. 2019. The role of trust in public attitudes towards invasive species management on Guam: A case study. J Environ Manag 229: 133-144.

Zimmermann HG, Neser S. 1999. Trends and prospects for biological control of weeds in South Africa. Afr Entomol Mem 1: 165-173. 